\title{
PENGARUH PERENDAMAN NATRIUM BIKARBONAT \\ TERHADAP KARAKTERISTIK TEPUNG IKAN TERI \\ SEBAGAI SUMBER FOSFOR DAN KALSIUM
}

\author{
Christina Litaay ${ }^{\star}$, Ashri Indriati, \\ Cahya Edi Wahyu Anggara, Hendarwin M. Astro \\ Pusat Penelitian Teknologi Tepat Guna, LIPI Subang, Jawa Barat \\ Jalan KS. Tubun, Cigadung, Subang Jawa Barat 41213 \\ Diterima: 16 Desember 2020/Disetujui: 14 Juni 2021 \\ *Korespondensi: christina_litaay@yahoo.com
}

\begin{abstract}
Cara sitasi: Litaay C, Indriati A, Mayasti NKI, Anggara CEW, Astro HM. 2021. Pengaruh perendaman natrium bikarbonat terhadap karakteristik tepung ikan teri sebagai sumber fosfor dan kalsium. Jurnal Pengolahan Hasil Perikanan Indonesia. 24(2): 148-159.
\end{abstract}

\begin{abstract}
Abstrak
Ikan teri memiliki sumber nutrisi penting dan nilai ekonomis yang tinggi, tetapi belum dapat dimanfaatkan secara maksimal. Bentuk pengolahan ikan teri yang dilakukan adalah memanfaatkan ikan teri dalam bentuk tepung sumber protein, kalsium dan fosfor. Penelitian ini bertujuan untuk menentukan pengaruh perendaman dalam natrium bikarbonat 0,8\% terhadap kadar kalsium dan fosfor tepung ikan teri. Perlakuan yang dilakukan adalah proses perendaman ikan dalam natrium bikarbonat $0,8 \%$ dengan variasi lama perendaman 15 menit (D1), 30 menit (D2), dan 45 menit (D3). Parameter dalam penelitian yang diamati antara lain kadar abu, kadar air, kadar protein, kadar lemak, kadar kalsium, dan kadar fosfor. Hasil penelitian menunjukkan bahwa perendaman ikan selama 30 menit memberikan kadar kalsium dan fosfor yang tertinggi masing-masing 6.136,33 $\pm 53,85 \mathrm{mg} / 100 \mathrm{~g}$ (bk) dan $31.915,20 \pm 235,30 \mathrm{mg} / \mathrm{kg}$ (bk), dengan kadar protein sebesar 66,25 $\pm 0,01 \%$ (bk).
\end{abstract}

Kata kunci: fosfor, ikan teri, kalsium, perendaman, tepung ikan

\section{Effects of Sodium Bicarbonate Immersion on Characteristics of Anchovy Flour as a Source of Phosphorus and Calcium}

\begin{abstract}
Anchovy is an important source of nutrients and of high economic value, however they are currently being underutilized. Anchovy can be processed into flour and becomes a source of protein, calcium, and phosphorus. This study was aimed to determine the effect of immersion times in $0.8 \%$ sodium bicarbonate on the calcium and phosphor content of the anchovy flour. Three immersion times (15 minutes (D1), 30 minutes (D2), and 45 minutes (D3)) were evaluated for their effect on the ash content, water content, protein content, fat content, calcium content, and phosphorus content. The 30-minute immersion time resulted the highest levels of calcium and phosphorus with content of $6,136.33 \pm 53.85 \mathrm{mg} / 100 \mathrm{~g}(\mathrm{db}) \mathrm{dan}$ $31,915.20 \pm 235.30 \mathrm{mg} / \mathrm{kg}(\mathrm{db})$, respectively and protein content of $66.25 \pm 0.01 \%(\mathrm{db})$.
\end{abstract}

Keyword: anchovy, calcium content, flour, immersion, phosphor content 


\section{PENDAHULUAN}

Teri (Stolephorus sp.) adalah ikan yang berukuran kecil dan mempunyai keistimewaan karena seluruh bagian tubuhnya dapat dikonsumsi seperti kepala, bagian daging bahkan tulang ikan. Ikan teri memiliki sumber nutrisi penting dan nilai ekonomis yang tinggi, karena dimanfaatkan sebagai lauk pauk makanan masyarakat Indonesia setiap hari. Ikan teri selain mudah didapat dan diolah dalam berbagai bentuk menu masakan, juga dapat dikonsumsi untuk semua kalangan usia (Nasution et al. 2018). Ikan teri adalah jenis ikan kecil tinggi protein dan sumber kalsium terbaik karena memiliki kandungan kalsium yang bersifat tidak mudah larut dan tahan dalam air. Kandungan gizi yang dimiliki ikan teri selain sebagai sumber protein dan kalsium adalah salah satu sumber fosfor. Konsumsi ikan teri dapat memberikan manfaat dalam meningkatkan densitas tulang dan mencegah terjadinya pengeroposan tulang (osteoporosis), karena mengandung banyak kalsium dan fosfor (Fadhilah et al. 2013).

Ikan teri memiliki harga murah dan dapat diperoleh di pasar, jika dibandingkan dengan ikan jenis lain. Ikan teri merupakan ikan yang tidak terlalu berbau amis karena memiliki kadar lemak yang rendah dan kandungan urea yang tidak terlalu tinggi (Isnanto 2012). Kelebihan teri antara lain seluruh tubuh termasuk tulang dapat dikonsumsi, sumber kalsium atau zat kapur (Ca), tinggi kandungan gizi, dan harga yang relatif murah untuk masyarakat dengan pendapatan rendah (Perana 2003). DepKes (2005) menjelaskan bahwa ikan teri segar memiliki kandungan gizi antara lain energi $77 \mathrm{kkal}$, fosfor $500 \mathrm{mg}$, lemak $1 \mathrm{~g}$, besi $0,05 \mathrm{mg}$, protein 16 gram, dan kalsium 500 mg dengan kadar protein ikan teri segar per $100 \mathrm{~g}$ adalah 10,3 g (Rustanti 2013). Keistimewaan ikan teri yang dapat dikonsumsi seluruh tubuhnya menjadikan ikan teri sebagai sumber kalsium, fosfor dan protein tinggi.

Masyarakat Indonesia umumnya mengetahui dan memahami bahwa susu merupakan sumber kalsium utama, namun kenyataannya ikan teri adalah sumber kalsium lain yang memiliki kandungan kalsium lebih besar. Nasoetion et al. (2009) melaporkan ikan teri memiliki kandungan kalsium sebesar 2,381 mg lebih besar dari kandungan kalsium susu sapi sebesar $143 \mathrm{mg}$. Putra (2013) melakukan penelitian tentang perbedaan kandungan kalsium $(\mathrm{Ca})$ pada susu sapi lokal dan ikan teri nasi, menghasilkan perbedaan signifikan yaitu kandungan kalsium susu sapi sebesar 106,32 mg per $100 \mathrm{~g}$ lebih rendah dibandingkan kalsium ikan teri sebesar 330,10 mg per $100 \mathrm{~g}$. Ikan teri memiliki kandungan kalsium lebih tinggi daripada susu sebesar 972 mg per 100 g (Persatuan Ahli Gizi Indonesia 2009).

Kalsium merupakan zat gizi mikro yang sangat penting selain fosfor untuk pertumbuhan linier anak (Stuijvenberg et al. 2015; Mikhail et al. 2013). Dewi dan Adhi (2016) melaporkan kalsium dan fosfor sangat penting dalam proses mineralisasi tulang, sehingga asupan yang kurang dari kedua mineral ini pada balita dapat memengaruhi pertumbuhan tulang, dan jika dibiarkan dalam waktu yang lama dapat menyebabkan tengkes (stunting). Tingginya zat gizi kalsium dan protein sangat diperlukan oleh tubuh untuk proses perbaikan dan membangun jaringan, terutama jaringan tulang dan gigi (Aryati dan Dharmayanti 2014). Defisiensi kalsium dan fosfor pada anak-anak dan remaja dapat memengaruhi struktur dasar tulang yang berakibat pada gagalnya pertumbuhan (Abrams 2001; Singh 2004).

Pemanfaatan dan peningkatan nilai tambah ikan teri sebagai salah satu bahan alternatif penambah gizi seperti kalsium, fosfor, dan protein dapat digunakan sebagai bahan fortifikasi pada produk pangan. Salah satu cara pengolahan pada ikan teri adalah mengolahnya menjadi tepung ikan (Ghaisany et al. 2018). Konsumsi makanan dapat ditingkatkan melalui penggunaan tepung ikan sebagai sumber protein (Solangi et al. 2002). Komposisi kimia tepung ikan yaitu lemak $2,54 \%$, protein kasar $60 \%$, kadar abu 1,2\% dan kadar air 2,5\% (Jassim 2010). Beberapa penelitian terkait kandungan gizi pada tepung ikan teri telah dilakukan secara tradisional maupun perendaman dalam asam di antaranya adalah penelitian Hendrayati et al. (2020) yaitu ikan teri yang 
direndam dalam air jeruk nipis 0,2-0,3\% selama 1 jam memiliki kadar kalsium 504 mg. Rahmi et al. (2018) telah melakukan penelitian tepung ikan teri nasi yang dikeringkan menggunakan oven bersuhu $80{ }^{0} \mathrm{C}$ selama 5 jam menghasilkan tepung dengan kadar kalsium sebesar 3219 mg/100 g. Nurani et al. (2018) melaporkan tepung ikan teri memiliki kadar kalsium 645,37 mg. Kandungan kalsium tepung teri hasil proses penggilingan dan pengayakan setelah proses pengeringan selama \pm 24 jam sebesar 2.000 $\mathrm{mg} / 100 \mathrm{~g}$ (Iwansyah et al. 2008). Tepung ikan teri memiliki kadar kalsium sebesar 4.608 $\mathrm{mg} / 100 \mathrm{~g}$, dan kadar fosfor sebesar $1.200 \mathrm{mg} /$ $\mathrm{kg}$ (Machmud et al. 1990).

Natrium bikarbonat atau soda kue merupakan salah satu alkali yang dapat digunakan dalam proses perendaman ikan teri. Penggunaan natrium bikarbonat dapat meningkatkan kandungan protein miofibril (Santoso et al. 2011). Studi Litaay (2012) menunjukkan bahwa penggunaan natrium bikarbonat $0,8 \%$ dapat meningkatkan kadar protein tepung ikan cakalang dari $76,55 \%$ tanpa deffating meningkat menjadi $82,86 \%$. Hasil penelitian ini sesuai dengan penelitian Subatin (2004) yaitu penggunaan natrium bikarbonat dapat meningkatkan kadar protein. Protein sangat penting dalam proses metabolisme kalsium terutama pada proses kalsifikasi tulang dan gigi (Aryati et al. 2014). Ikan teri merupakan hasil perikanan yang mudah busuk dan rusak karena mengandung kadar air tinggi sebesar 84,05\% (Fahmi et al. 2014), sehingga dapat memengaruhi daya simpan tepung ikan. Proses perendaman ikan cakalang dalam natrium bikarbonat $0,8 \%$ selama 120 menit, menghasilkan tepung ikan dengan kadar air rendah $6,89 \%$ jika dibandingkan kadar air tanpa perendaman sebesar 12,82\% (Litaay 2012; Litaay dan Santoso 2013).

Berdasarkan uraian tersebut maka sangat penting dilakukan penelitian terkait penggunaan natrium bikarbonat dalam proses pembuatan tepung ikan teri untuk menghasilkan tepung ikan dengan kadar kalsium dan fosfor yang tinggi. Penelitian ini bertujuan untuk mengetahui perlakuan terbaik lama perendaman dalam natrium bikarbonat
0,8\% yang menghasilkan karakteristik tepung ikan teri terbaik berdasarkan kadar kalsium dan kadar fosfor yang paling tinggi.

\section{BAHAN DAN METODE Bahan dan Alat}

Bahan utama yang digunakan adalah ikan teri (Stolephorus sp.) segar dengan panjang total berkisar antara 3,7-9,5 cm dengan berat 1,0-6,0 g yang diperoleh dari Blanakan Subang, serta natrium bikarbonat 0,8\% dan air untuk proses perendaman. Bahanbahan untuk pengujian antara lain bahan pengujian proksimat, kadar kalsium dan kadar fosfor. Bahan kimia yang digunakan untuk karakterisasi tepung ikan adalah pelarut lemak berupa N-heksan, selenium, $\mathrm{H}_{2} \mathrm{SO}_{4}$ pekat, $\mathrm{NaOH}$, akuades, $\mathrm{H}_{3} \mathrm{BO}_{3}, \mathrm{HCl}$, dan indikator bromokresol hijau-metil merah berwarna merah muda, larutan $\mathrm{Na}_{2}$ EDTA, dan bufer amonium klorida. Peralatan yang digunakan dalam penelitian yaitu timbangan analitik, pressure cooker, alat press (PressTokyo Jepang), laboratory oven, blender (merk Panasonic), dan saringan 60 mesh, labu erlenmeyer (Pyrex), labu soxhlet (Kimax), kertas saring, cawan porselen (Duran), oven (Heraeus instrument), hot plate, desikator (csn simax), tanur (Furnace thermolyne), labu kjeldahl (Duran dan Pyrex), timbangan digital (Fisher scientific), dan spektrofotometer.

\section{Metode Penelitian}

Dalam penelitian terdapat dua tahap pelaksanaan yaitu proses pembuatan tepung ikan teri dan karakterisasi tepung ikan yang dihasilkan. Proses pembuatan tepung ikan teri dilakukan dengan menggunakan natrium bikarbonat $0,8 \%$ dengan perlakuan lama perendaman ikan teri yang berbeda yaitu 15 menit (D1), 30 menit (D2), dan 45 menit (D3). Penentuan media perendaman natrium bikarbonat $0,8 \%$ didasarkan pada penelitian Litaay (2012) yaitu natrium bikarbonat $0,8 \%$ merupakan media perendaman dengan konsentrasi terbaik dalam menentukan karakteristik kimia tepung ikan cakalang (Katsuwonus pelamis), selain itu perendaman ikan motan (Thynnichthys thynnoides) dalam natrium bikarbonat $0,8 \%$ menghasilkan kadar protein dan kadar abu yang tinggi 
(Irsalina et al. 2016). Lama perendaman dengan taraf $(15,30$, dan 45 menit) merupakan rentang waktu yang digunakan dalam perendaman ikan teri (Rasyid 2010). Data kadar kalsium dan fosfor tepung ikan teri masing-masing sebesar $4.608 \mathrm{mg} / 100 \mathrm{~g}$ dan $1.200 \mathrm{mg} / \mathrm{kg}$ dijadikan kontrol tepung ikan teri (Machmud et al. 1990).

\section{Pembuatan tepung ikan teri}

Pembuatan tepung ikan teri mengacu pada Litaay (2012) dengan modifikasi lama perendaman. Pembuatan tepung ikan diawali proses pencucian, selanjutnya dilakukan proses perendaman ikan dalam natrium bikarbonat $0,8 \%$ dengan variasi lama perendaman 15 menit (D1), 30 menit (D2), dan 45 menit (D3). Proses berikutnya adalah dilakukan perebusan pada suhu $80^{\circ} \mathrm{C}$ selama 15 menit, selanjutnya proses pengepresan ikan selama 10 menit, dan pengeringan pada suhu $55^{\circ} \mathrm{C}$ selama 5 jam, kemudian penghalusan dengan blender dan penepungan dengan saringan 60 mesh.

\section{Analisis tepung ikan teri}

Analisis tepung ikan dalam penelitian ini antara lain komposisi proksimat (kadar air, kadar lemak, kadar abu, dan kadar protein), kadar kalsium, dan kadar fosfor. Kadar air dianalisis menggunakan metode termogravimetri dengan mengacu pada SNI 01-2891-1992 butir 5.1 (BSN 1992), kadar lemak dianalisis menggunakan metode sokhlet dengan mengacu pada 18-8-5/MU/SMM-SIG butir 3.2.1 (Saraswanti Indo Genetech 2019), kadar abu dianalisis menggunakan SNI 012891-1992, 6.1 (BSN 1992), kadar protein dianalisis menggunakan metode Kjeltec dengan mengacu pada 18-8-31/MU/SMMSIG (Saraswanti Indo Genetech 2019), dan energi total dianalisis menggunakan metode kalkulasi. Perhitungan kalsium dan fosfor dianalisis menggunakan metode ICP OES dengan mengacu pada 18-13-1/MU/SMMSIG (Saraswanti Indo Genetech 2019).

\section{Analisis Data}

Penelitian ini menggunakan RAL (rancangan acak lengkap) satu faktor dengan tiga perlakuan (Steel dan Torrie 1993). Perlakuan antara lain lama perendaman 15 menit (D1), 30 menit (D2), dan 45 menit (D3), dengan pengulangan dua kali. Data yang dianalisis meliputi kadar kalsium, kadar fosfor dan proksimat (kadar abu, kadar air, kadar lemak, dan kadar protein). Data dianalisis secara ANOVA (analisis ragam) dan dilanjutkan uji BNT (beda nyata terkecil) jika terdapat perbedaan pada perlakuan.

\section{HASIL DAN PEMBAHASAN Kadar Abu}

Kadar abu tepung ikan teri dapat dilihat pada Table 1. Kadar abu tepung ikan yaitu $14,67 \pm 0,12 \%-15,96 \pm 0,14 \%$ (bk). Hasil analisis statistik menunjukkan bahwa lama perendaman dalam natrium bikarbonat $0,8 \%$ berpengaruh nyata $(p<0,05)$ terhadap kadar abu. Kadar abu pada perlakuan lama perendaman 30 menit menunjukkan tidak berbeda nyata dengan lama perendaman 45 menit. Kadar abu tertinggi tepung ikan teri diperoleh pada perendaman natrium bikarbonat $0,8 \%$ dengan lama perendaman 15 menit sebesar $15,96 \pm 0,14 \%$ (bk) sedangkan terendah pada perlakuan lama perendaman 30 menit $14,67 \pm 0,12 \%$ (bk).

Kadar abu pada penelitian ini tergolong lebih tinggi jika dibandingkan dengan penelitian-penelitian yang sebelumnya. Kadar abu pada penelitian Pomanto et al. (2016) tepung ikan manggabai hanya sebesar $0,94 \%$ $3,42 \%$; tepung ikan cakalang sebesar 2,89\%

Table 1 The nutritional value of anchovy flour based on the variation of immersion time

\begin{tabular}{lcccc}
\hline $\begin{array}{c}\text { Treatment } \\
\text { Immersion time })\end{array}$ & $\begin{array}{c}\text { Ash content } \\
(\%, \mathrm{db})\end{array}$ & $\begin{array}{c}\text { Moisture content } \\
(\%, \mathrm{db})\end{array}$ & $\begin{array}{c}\text { Lipid content } \\
(\%, \mathrm{db})\end{array}$ & $\begin{array}{c}\text { Protein content } \\
(\%, \mathrm{db})\end{array}$ \\
\hline D1 (15 minutes) & $15.96 \pm 0.14^{\mathrm{a}}$ & $14.22 \pm 0.15^{\mathrm{a}}$ & $4.50 \pm 0.08^{\mathrm{a}}$ & $63.59 \pm 0.18^{\mathrm{a}}$ \\
D2 (30 minutes) & $14.67 \pm 0.12^{\mathrm{b}}$ & $13.15 \pm 0.04^{\mathrm{b}}$ & $5.27 \pm 0.16^{\mathrm{b}}$ & $64.79 \pm 0.22^{\mathrm{b}}$ \\
D3 (45 minutes) & $14.88 \pm 0.15^{\mathrm{b}}$ & $11.48 \pm 0.07^{\mathrm{c}}$ & $6.71 \pm 0.14^{\mathrm{c}}$ & $66.25 \pm 0.01^{\mathrm{c}}$ \\
\hline
\end{tabular}

Note: different letter in the same column indicate significant difference $(p<0.05)$ 
(Litaay 2012; Litaay dan Santoso 2013); dan penelitian Orlan et al. (2019) tepung ikan beho berkisar antara 9,27-9,39\%. Kadar abu tepung ikan teri juga masih lebih tinggi jika dibandingkan dengan kadar abu tepung ikan teri tanpa perlakuan yaitu sebesar 10,25\% (Nurani et al. 2018), perendaman dalam media air selama 30 menit sebesar 4,82\% (Canti et al. 2021), dan perendaman dalam air jeruk nipis $0,2-0,3 \%$ selama 1 jam yaitu sebesar 7,76\% (Hendrayati et al. 2020). Penggunaan natrium bikarbonat $0,8 \%$ sebagai media perendaman dapat meningkatkan kadar abu tepung ikan karena senyawa natrium bikarbonat mengandung unsur natrium yang merupakan komponen mineral. Litaay (2012) serta Litaay dan Santoso (2013) menjelaskan bahwa tepung ikan cakalang memiliki kadar abu tertinggi pada media perendaman natrium bikarbonat $0,8 \%$ dibandingkan media air dan media asam asetat 3\%. Perendaman ikan motan dalam natrium bikarbonat $0,8 \%$ menghasilkan kadar abu yang tinggi sebesar 14,20\% (Irsalina et al. 2016).

Hasil penelitian menunjukkan bahwa kadar abu tepung ikan perendaman natrium bikarbonat $0,8 \%$ dengan lama perendaman 15 menit, 30 menit dan 45 menit masing-masing $15,96 \%$; $14,67 \%$; dan $14,88 \%$ memenuhi standar kadar abu dengan mutu I maksimum 20\% (BSN 1996). Tingginya kadar abu ikan teri disebabkan karena ikan teri adalah jenis ikan kecil yang seluruh bagian tubuhnya dapat dikonsumsi mulai dari kepala, daging bahkan tulangnya (Murdiati dan Amaliah 2013). Tingginya kadar abu pada produk hewani disebabkan karena adanya kandungan mineral antara lain kalsium, fosfor, dan besi (Winarno 2007).

\section{Kadar Air}

Tepung ikan teri memiliki kadar air sebesar $\quad 11,48 \pm 0,07 \%-14,22 \pm 0,15 \% \quad$ (bk) (Table 1). Hasil analisis statistik menunjukkan adanya pengaruh nyata $(p<0,05)$ perendaman natrium bikarbonat $0,8 \%$ terhadap kadar air. Kadar air pada perlakuan 15 menit, 30 menit, dan 45 menit berbeda nyata/adanya perbedaan signifikan. Kadar air terendah dihasilkan pada perendaman dalam natrium bikarbonat $0,8 \%$ selama 45 menit sebesar 11,48\% $\pm 0,07$ (bk).
Tepung ikan teri hasil penelitian memiliki kadar abu yang tidak jauh berbeda dengan hasil penelitian Koning (2002) sebesar 12,65\%. Kadar air ini lebih rendah dari penelitian dengan penelitian Orlan et al. (2019) dimana kadar air tepung ikan sebesar $18,86 \%$, tetapi lebih tinggi dari penelitian Jayadi dan Rahman (2018) pada tepung ikan duo sebesar 5,39\%; dan tepung ikan manggabai yaitu antara $2,74 \%$ - 4,77\% (Pomanto et al. 2016).

Kadar air tepung ikan teri cenderung mengalami penurunan jika dibandingkan dengan hasil penelitian Fetriyuna et al. (2011) yaitu kadar air tepung ikan teri tanpa perlakuan sebesar $20,13 \%$. Hasil ini sejalan dengan penelitian (Litaay 2012; Litaay dan Santoso 2013) yaitu kadar air tepung ikan cakalang tanpa perlakuan perendaman sebesar $12,82 \%$ menurun menjadi $6,89 \%$ pada perendaman natrium bikarbonat $0,8 \%$ selama 2 jam.

Nandhani dan Yunianta (2015) melaporkan bahwa adanya konsentrasi natrium bikarbonat menyebabkan kadar air cenderung menurun. Natrium bikarbonat memiliki sifat yaitu kemampuan menghasilkan gas $\mathrm{CO}_{2}$. Gas $\mathrm{CO}_{2}$ yang dihasilkan natrium bikarbonat dengan adanya panas (Wood 1989). Kemampuan natrium bikarbonat menghasilkan $\mathrm{CO}_{2}$ dapat membentuk rongga atau pori. Rongga atau pori yang terbentuk dapat memperluas permukaan bahan sehingga air mudah keluar saat produk dipanaskan (Winarno 2004). Natrium bikarbonat memiliki sifat yang dapat menghasilkan rongga atau pori pada permukaan tulang ikan, sehingga dapat menurunkan kadar air (Herpandi et al. 2019).

Berdasarkan BSN (1996), standar kadar air dengan mutu II maksimum 12\%, maka kadar air yang memenuhi kriteria mutu adalah perlakuan perendaman natrium bikarbonat selama 45 menit sebesar $11,48 \%$, sedangkan perlakuan lama perendaman selama 15 menit dan 30 menit hampir memenuhi syarat mutu II maksimal kadar air yang disyaratkan. Kadar air tepung ikan teri yang tinggi diduga dipengaruhi oleh tebalnya tumpukan bahan ikan saat pengaturan dalam nampan sehingga proses pengeringan tidak merata. Pengeringan bertujuan untuk menurunkan kadar air 
bahan dan pada proses pengeringan sering dijumpai adanya variasi kadar air bahan yang dipengaruhi oleh tebalnya tumpukan bahan, kadar air awal bahan serta RH udara pengering (Brooker et al. 1974). Kusumaningrum et al. (2016) melaporkan bahwa kadar air yang rendah dapat menghambat pertumbuhan bakteri sehingga daya awet produk lebih lama, namun jika kadar air tinggi maka akan terjadi penurunan mutu produk dan menjadi rusak akibat aktivitas mikroba (Kusnandar 2010).

\section{Kadar Lemak}

Kadar lemak tepung ikan teri dengan lama perendaman yang berbeda dalam natrium bikarbonat $0,8 \%$ dapat dilihat pada Table 1 . Kadar lemak tepung ikan teri hasil penelitian berkisar antara $4,50 \pm 0,08 \%-6,71 \pm 0,14 \%$ (bk). Analisis statistik menunjukkan bahwa lama perendaman dalam natrium bikarbonat $0,8 \%$ berpengaruh nyata $(p<0,05)$ terhadap kadar lemak tepung ikan teri. Lama perendaman 15 menit memiliki kadar lemak yang

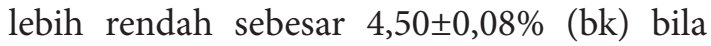
dibandingkan dengan perlakuan 30 menit sebesar $5,27 \pm 0,16 \%$ (bk) dan perlakuan 45 menit sebesar 6,71 $00,14 \%$ (bk).

Kadar lemak hasil penelitian ini lebih rendah dari hasil penelitian Koning (2002) pada tepung ikan (ikan teri, mata merah, atau pilchard) sebesar 10,28\%-14,49\%, namun lebih tinggi dari penelitian Litaay (2012) serta Litaay dan Santoso (2013) pada tepung ikan cakalang sebesar 0,89\%-1,10\%. Jika dibandingkan dengan kadar lemak tepung ikan teri penelitian Turan et al. (2007) sebesar 8,57\%-9,14\% maka kadar lemak ikan teri hasil penelitian masih rendah. Penggunaan natrium bikarbonat sebagai media perendaman dapat mengurangi kadar lemak, hal ini disebabkan karena natrium bikarbonat bersifat alkali sehingga mampu meminimumkan lemak suatu produk. Nolsoe dan Ingrid (2009) menjelaskan bahwa penggunaan asam dan alkali mampu meminimumkan lemak atau menghilangkan lemak, selain itu mampu membuka struktur ikatan matriks pada tulang yang memungkinkan lemak dan senyawa lainnya dengan mudah terlepas (Cho et al. 2005).
Penurunan kadar lemak sangat berpengaruh terhadap daya awet bahan, apabila kadar lemak bahan tinggi maka akan mempercepat ketengikan akibat terjadinya oksidasi lemak (Ketaren 2005). Fahmi et al. (2015) menjelaskan bahwa kadar lemak pada tepung ikan dapat menurun selama penyimpanan akibat proses oksidasi. Hasil penelitian menunjukkan bahwa kadar lemak tepung ikan perendaman natrium bikarbonat dengan lama perendaman 15 menit, 30 menit dan 45 menit masing-masing 4,50\%; 5,27\%; dan $6,71 \%$ memenuhi standar kadar lemak dengan mutu I maksimum 8\% (BSN 1996).

\section{Kadar Protein}

Kadar protein tepung ikan teri dapat dilihat pada Table 1. Kadar protein pada tepung ikan teri yaitu antara $63,59 \pm 0,18 \%$ $66,25 \pm 0,01 \%$ (bk). Hasil uji statistik menunjukkan adanya pengaruh nyata $(p<0,05)$ antar perlakuan lama perendaman terhadap kadar protein. Perlakuan perendaman selama 45 menit memiliki kadar protein yang tinggi sebesar $66,25 \pm 0,01 \%$ (bk). Kadar protein hasil penelitian ini masih tergolong lebih tinggi jika dibandingkan dengan kadar protein tepung ikan lain seperti tepung ikan belida sebesar 20,73-21,32\% (Norman et al. 2006) dan tepung ikan cakalang (beho) yang diberi tepung bawang putih (Allium sativum) sebesar 27,57\%-29,99\% (Orlan et al. 2019). Kadar protein pada penelitian ini hampir sama dengan hasil penelitian Koning (2002) pada tepung ikan yang menggunakan pengeringan uap sebesar 61,56\%-68,26\%. Cho dan Kim (2010) berpendapat bahwa tepung ikan yang berkualitas baik mengandung protein antara $60 \%$ dan $72 \%$.

Kadar protein tepung ikan teri tanpa perlakuan penelitian Fetriyuna et al. (2011) sebesar 53,15\% masih lebih rendah jika dibandingkan dengan kadar protein tepung ikan teri hasil penelitian. Lama perendaman tepung ikan dalam natrium bikarbonat $0,8 \%$ menyebabkan kadar protein meningkat. Litaay (2012) serta Litaay dan Santoso (2013) melaporkan bahwa kadar protein tepung ikan cakalang pada perendaman natrium bikarbonat $\quad 0,8 \%$ selama 2 jam sebesar 
Table 2 The nutritional value of calcium and phosphorus of anchovy flour in the variation of immersion time

\begin{tabular}{lcr}
\hline $\begin{array}{c}\text { Treatment } \\
\text { (Immersion time })\end{array}$ & $\begin{array}{c}\text { Calcium } \\
(\mathrm{mg} / 100 \mathrm{~g}, \mathrm{db})\end{array}$ & \multicolumn{1}{c}{$\begin{array}{l}\text { Phosphorus } \\
(\mathrm{mg} / \mathrm{kg}, \mathrm{db})\end{array}$} \\
\hline D1 (15 minutes) & $5,701.52 \pm 36.23^{\mathrm{a}}$ & $29,469.99 \pm 63.18^{\mathrm{a}}$ \\
D2 (30 minutes) & $6,136.33 \pm 53.85^{\mathrm{b}}$ & $31,915.20 \pm 235.30^{\mathrm{b}}$ \\
D3 (45 minutes) & $5,930.07 \pm 100.32^{\mathrm{b}}$ & $31,112.01 \pm 144.29^{\mathrm{c}}$ \\
\hline
\end{tabular}

Note: different letter in the same column indicate significant difference $(p<0.05)$

$77,67 \%$ meningkat sebesar $82,86 \%$ selama 6 jam. Tepung ikan motan memiliki kadar protein sebesar $63,90 \%$ pada perendaman natrium bikarbonat $0,8 \%$ (Irsalina et al. 2016). Santoso et al. (2011) menjelaskan bahwa penggunaan natrium bikarbonat meningkatkan protein miofibril, dan mempunyaikemampuanuntuk mengikat suatu molekul air. Molekul air akan terperangkap dalam struktur gel yang dibentuk oleh natrium bikarbonat, sehingga protein pada bahan yang turut larut dalam air juga akan ikut terperangkap dan mengakibatkan kadar protein meningkat atau dapat dipertahankan.

Subatin (2004) menjelaskan bahwa kadar protein dapat meningkat sejalan dengan adanya penggunaan bahan natrium bikarbonat. Selain itu meningkatnya kandungan protein dipengaruhi jumlah asam amino yang terdapat pada bahan. Protein memiliki peranan penting dalam penyerapan kalsium, dimana protein berperan sebagai pengikat kalsium antara lain arginin dan asam amino lisin (Harland dan Oberleas 2001). Pudyani (2005) menjelaskan bahwa protein berkaitan dengan kalsium, yaitu kalsium dalam plasma sebesar $40 \%$ terikat dengan protein. Protein berfungsi sebagai sumber cadangan untuk kalsium serta berpengaruh dalam proses metabolisme kalsium untuk kalsifikasi gigi dan tulang. Kekurangan protein akan menyebabkan kekuatan dan elastisitas tulang dan gigi berkurang, terutama tulang rahang (Bozzini et al. 2011).

Berdasarkan BSN (1996), standar kadar protein dengan mutu I maksimum 65\%, maka kadar protein tepung ikan dengan perendaman natrium bikarbonat selama 15 menit dan 30 menit masing-masing sebesar $63,59 \%$ dan $64,79 \%$ memenuhi kriteria mutu I tepung ikan. Sedangkan perendaman selama
45 menit memiliki kadar protein yang lebih tinggi dari syarat mutu I sebesar $66,25 \%$.

\section{Kadar Kalsium}

Kadar kalsium tepung ikan teri dapat dilihat pada Table 2. Analisis statistik menunjukkan adanya pengaruh nyata $(p<0,05)$ perendaman natrium bikarbonat $0,8 \%$ terhadap kadar kalsium. Kadar kalsium tertinggi terdapat pada tepung ikan teri dengan lama perendaman 30 menit sebesar $6.136,33 \pm 53,85 \%$ (bk) namun tidak berbeda nyata dengan lama perendaman 45 menit sebesar 5.930,07 $\pm 100,32 \%$ (bk).

Hasil penelitian kadar kalsium tepung ikan teri lebih tinggi dari kadar kalsium tepung ikan gabus yaitu 16,86\%-22,77\% (Cucikodana et al. 2012), dan kadar kalsium tepung tulang ikan nila antara 18,7\%-21,48\% (Lakahena et al. 2014). Kadar kalsium tepung ikan teri juga masih lebih tinggi jika dibandingkan dengan kadar kalsium tepung ikan teri tanpa perlakuan sebesar $4.608 \mathrm{mg} / 100 \mathrm{~g}$ (Machmud et al. 1990), kadar kalsium tepung ikan teri yang dikeringkan pada suhu $80{ }^{\circ} \mathrm{C}$ selama 5 jam sebesar 3.219 mg/100 g (Rahmi et al. 2018), dan kadar kalsium ikan teri dengan perendaman dalam air jeruk nipis $0,2-0,3 \%$ selama 1 jam yaitu sebesar $504 \mathrm{mg} / 100 \mathrm{~g}$ (Hendrayati et al. 2020). Penggunaan natrium bikarbonat dapat meningkatkan kadar kalsium tepung ikan teri karena senyawa natrium bikarbonat mengandung unsur natrium yang merupakan komponen mineral.

Ikan teri merupakan pangan sumber protein, dan sumber kalsium. Hal ini terlihat dari tingginya kadar kalsium ikan teri nasi sebesar $972 \mathrm{mg}$ per $100 \mathrm{~g}$ dibandingkan susu (Rustanti 2013). Purnasari et al. (2016) menjelaskan bahwa kandungan kalsium yang 
dimiliki ikan teri sangat tinggi dan memiliki bioavailabilitas kalsium setara dengan produk susu untuk asupan kalsium pada tingkat marginal. Kadar kalsium tepung ikan teri tinggi karena ukuran ikan yang sangat kecil dan dimakan utuh dengan tulangnya (Rahmi et al. 2018). Burr (2002) menjelaskan bahwa peningkatan pembentukan kristal hidroksiapatit akibat adanya pengendapan ion kalsium dan fosfat pada matriks tulang dapat memengaruhi meningkatnya densitas tulang. Nutrisi kalsium yang tinggi sangat penting untuk masyarakat terlebih bagi balita dan ibu hamil karena berhubungan dengan pertumbuhan dan perkembangan gigi dan tulang anak.

\section{Kadar Fosfor}

Kadar fosfor tepung ikan hasil penelitian dapat dilihat pada Table 2. Kadar fosfor tepung ikan teri dengan variasi lama waktu perendaman dalam natrium bikarbonat $0,8 \%$ berkisar antara $29.469,99 \pm 63,18 \mathrm{mg} /$ kg-31.915,20 $235,30 \quad \mathrm{mg} / \mathrm{kg} \quad$ (bk). Hasil analisis statistik menunjukkan bahwa lama perendaman memberikan pengaruh nyata $(p<0,05)$ terhadap kadar fosfor. Kadar fosfat yang tinggi dihasilkan pada perendaman dalam natrium bikarbonat $0,8 \%$ selama 30

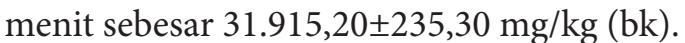

Kadar fosfor tepung ikan teri lebih tinggi jika dibandingkan dengan hasil penelitian Machmud et al. (1990) yaitu tepung ikan teri memiliki kadar fosfor sebesar $1.200 \mathrm{mg} /$ $\mathrm{kg}$, tepung tulang ikan patin sebesar 8,91\%11,78\% (Lekahena et al. 2014) dan kadar fosfor tepung tulang ikan tuna sebesar 11,34\%14,25\% (Trilaksani et al. 2006). Evawati (2010) menyatakan bahwa mengonsumsi makanan yang mengandung fosfor dapat meningkatkan bioavailabilitas kalsium. Fosfor adalah salah satu mineral yang terbanyak dalam tubuh, dan jumlahnya hanya dilampaui oleh kalsium. Mineral terbagi atas mineral mikro dan mineral makro.

Perbedaan variasi lama waktu perendaman pada proses pembuatan tepung ikan akan sangat memengaruhi karakteristik dari tepung ikan yang dihasilkan. Kaya et al. (2008) menjelaskan bahwa metode, penggunaan suhu, dan perbedaan waktu dapat menunjukkan nilai fosfor tepung ikan berbeda. Dalam kondisi basa atau alkali, kalsium dan fosfor dalam tulang dapat membentuk kristal dari mineral tidak larut dalam alkali atau $\mathrm{pH}$ basa (Almatsier 2004).

Perbandingan kalsium dan fosfor sangat diperlukan dalam suatu absorbsi, sehingga diperlukan perbandingan 1:1 sampai 1:3 untuk kalsium dan fosfor dalam rongga usus. Perbandingan kalsium dan fosfor yang melebihi rasio 1:3 dapat mengakibatkan terjadinya penyerapan kalsium (Sediaoetama 2006). Menurut Nieves (2005), terjadinya resiko patah tulang disebabkan oleh kekurangan fosfor dan rendahnya asupan fosfor dapat menghambat fungsi dari osteoblas. Di dalam jaringan keras, fosfor lebih rendah jika dibandingkan dengan kalsium, sebaliknya fosfor lebih tinggi dalam jaringan lunak jika dibandingkan dengan kalsium (Ritonga dan Sukindro 2012). Almatsier (2002) menjelaskan bahwa untuk mencegah terjadinya perubahan tingkat keasamaan cairan pada tubuh, fosfat sangat berperan sebagai bufer, hal ini disebabkan adanya kemampuan fosfat dalam mengikat tambahan ion hidrogen.

\section{KESIMPULAN}

Tepung ikan teri yang dihasilkan dengan metode perendaman natrium bikarbonat 0,8\% menunjukkan karakteristik terbaik yaitu perendaman ikan selama30 menitmemberikan kadar kalsium dan fosfor yang tertinggi masing-masing $6.136,33 \pm 53,85 \mathrm{mg} / 100 \mathrm{~g}$ (bk) dan $31.915,20 \pm 235,30 \mathrm{mg} / \mathrm{kg}$ (bk), dengan kadar protein sebesar $66,25 \pm 0,01 \%$ (bk).

\section{UCAPAN TERIMA KASIH}

Penulis mengucapkan terima kasih kepada Lembaga Pengelola Dana Pendidikan (LPDP) Kementerian Keuangan yang telah memberikan dana penelitian melalui kegiatan Prioritas Riset Nasional (PRN) tahun 2020. Terima kasih juga penulis sampaikan kepada Kementerian Riset dan Teknologi (Kemenristek)/Badan Riset Inovasi Nasional (BRIN) sebagai pengelola riset dan Lembaga Ilmu Pengetahuan Indonesia (LIPI) dalam menunjang kegiatan riset, serta semua tim peneliti yang telah berpartisipasi dalam kegiatan riset. 


\section{DAFTAR PUSTAKA}

Abrams SA. Calcium turnover and nutrition through the life cycle. 2001. The Proceedings of the Nutrition Society. 60: 283-289.

Aisiyah, Rustanti N. 2013. Kandungan betakaroten, protein, kalsium, dan uji kesukaan crackers dengan substitusi tepung ubi jalar kuning (Ipomoea batatas L.) dan ikan teri nasi (Stolephorus sp.) untuk anak KEP dan KVA. Journal of Nutrition College. 2(1): 145-153.

Almatsier S. 2006. Prinsip Dasar Ilmu Gizi. Jakarta (ID): PT Gramedia Pustaka Utama.

Anggraen N, Darmanto YS, Riyadi PH. 2016. Pemanfaatan nano kalsium tulang ikan nila (Oreochromis niloticus) pada beras analog dari berbagai macam ubi jalar (Ipomoea batatas L.) Jurnal Aplikasi Teknologi Pangan. 5(4): 114-122.

Aryati EE, Dharmayanti AWS. 2014. Manfaat ikan teri segar (Stolephorus sp) terhadap pertumbuhan tulang dan gigi. ODONTO Dental Journal. 1(2): 52-56

Aryee FNA, Oduro I, Ellis WO, Afuakwa JJ. 2006. The physico-chemical properties of flour samples from the roots of 31 varieties of cassava. Journal Food Control. 17: 916-922.

Bozzini EC, Graciela C, Rosa MA, Clarissa B. 2011. Bone mineral density and bone strength from mandible of chronically protein restricted rat. Acto odontol latinoam. 24 (3): 223-228.

Brooker DB, Bakker-Arkena FW, Hall CW. 1974. Drying Cereal Grains. Westport, Connecticut: The AVI Publishing Co., Inc.

[BSN] Badan Standardisasi Nasional. 1996. SNI 01-2715-1996: Persyaratan Mutu Tepung Ikan. Jakarta (ID): Badan Standardisasi Nasional.

Burr DB. 2002. Bone material properties and mineral matrixs contributions to fracture risk or age in women and men. Journal Muskuloskeletal Neuron Interact. 2(3): 201-204.

Canti M, Hadi TC, Lestari D. 2021. Instant noodles from pumpkin (Cucurbita moschata D.) and anchovy flour
(Stolephorus commersini) as an alternative emergency food. Jurnal Gizi Pangan. 16(1): 37-44.

Cucikodana Y, Supriadi A, Purwanto B. 2012. Pengaruh perbedaan suhu perebusan dan konsentrasi $\mathrm{NaOH}$ terhadap kualitas bubuk tulang ikan gabus (Channa striata). Jurnal Fishtech. 1(1): 91-101.

Cho SM, Gu YS, Kim SB. 2005. Extracting optimization and physical properties of yellowfin tuna (Thunnus albacares) skin gelatin compared to mammalian gelatins. Food Hydrocolloids. 19(2): 221- 229.

Cho JH, Kim IH. 2010. Fish meal-nutritive value. Journal of Animal Physiology and Animal Nutrition. 95(6): 685-692.

Choirunisa RS, Susilo B, Nugroho WA. 2014. Pengaruh perendaman natrium bisulfit $\left(\mathrm{NaHSO}_{3}\right)$ dan suhu pengeringan terhadap kualitas pati umbi ganyong (Canna edulis Ker). Jurnal Bioproses Komoditas Tropis. 2(2): 116-122.

Dewi IA, Adhi KT. 2016. Pengaruh konsumsi protein dan seng serta riwayat penyakit infeksi terhadap kejadian stunting pada anak balita umur 24-59 bulan di wilayah kerja Puskesmas Nusa Penida III. Archive Community Health. 3(1): 36-46.

Direktorat Gizi Departemen Kesehatan Republik Indonesia. 2005. Daftar Komposisi Bahan Makanan. Jakarta (ID).

Evawati D. 2010. Pemanfaatan kerang fortifikasi kalsium pada kerupuk aneka rasa untuk peningkatan kandungan gizi dan tingkat penerimaan konsumen. Jurnal Akademi Keperawatan. 2(1): 3-17.

Fadhilah RN, Suhartini, Rahardyan. 2013. Perbandingan pemberian ikan teri (Stolephorus sp.) dan susu kedelai terhadap densitas mandibula tikus. Insisiva Dental Journal: Majalah Kedokteran Gigi Insisiva. 2(1):19-26.

Fahmi, Syahrul, Laksono T. 2015. Pengaruh pengolahan tepung ikan selama masa penyimpanan. Jurnal Perikanan dan Kelautan. 3(4): 41-50.

Fetriyuna, Yenrina R, Kasim A. 2011. Bioavaibility of protein and calcium in instant noodle with anchovy fish powder mixed. University of Padjajaran.

Ghaisany T, Liviawaty E, Rochima E, Afrianto 
E. 2018. Fortification of indian anchovy fish flour as a source of protein and calcium for preferences level flat rice noodles. Global Scientific Journal. 6(10): 27-36.

Harland FB, Oberleas D. 2001. Effect of dietary fiber and phytat in the homeostatis and bioavailability of mineral. Di dalam: Spiller AG, editors. Handbooks of Dietary Fiber in Human Nutrition. 3rd edition. USA: Library of Congress.

Hendrayati, Dewi T, Budyghifari L, Adam Adriyani. 2020. Proximate Characteristics and Nutritional Value of White Anchovy Flour. Medico-legal Update. 20(3): 744749.

Herpandi, Widiastuti I, Wulandari, Sari CA. 2019. Efektivitas natrium bikarbonat $\left(\mathrm{NaHCO}_{3}\right)$ terhadap karakteristik fisikokimia dan sensori keripik tulang ikan putak (Notopterus notopterus). Jurnal Pengolahan Hasil Perikanan Indonesia. 22(2): 263-272.

Irsalina R, Lestari SD, Herpandi. 2016. Karakteristik fisiko-kimia dan sensori mie kering dengan penambahan tepung ikan motan (Thynnichthys thynnoides). FishtecH Jurnal Teknologi Hasil Perikanan. 5(1): 32-42.

Isnanto T. 2012. Pembuatan opak dengan penambahan ikan teri (Stolephorus spp.) kaya protein. [Laporan tugas akhir]. Surakarta (ID): Universitas Sebelas Maret.

Iwansyah AC, Heminiati A, Setyoningrum F. 2008. The effect of fish bone flour addition as calcium resource to chemical properties of fish. Universitas Lampung.

Jassim JM. 2010. Effect of using local fish meal (Liza $a b u)$ as protein concentration in broiler diets. The Journal of Poultry Science. 9(12): 1097-1099.

Jayadi, Rahman Abd. 2018. Analisis kandungan gizi makro pada ikan duo (penja) hitam dan putih sebagai pangan lokal Kota Palu. Jurnal Gizi dan Kesehatan. 8(2): 31-38

Kaya AOW, Santoso J, Salamah E. 2008. Pemanfaatan tepung tulang ikan patin (Pangasius sp.) sebagai sumber kalsium dan fosfor dalam pembuatan biskuit. Jurnal Ichthyos. 7(1): 9-14.

Ketaren S. 2005. Pengantar Teknologi Minyak dan Lemak Pangan. Jakarta (ID): UI Press. Khuldi A, Kusumaningrum I, Asikin AN. 2006. Pengaruh lama perebusan terhadap karakteristik tepung tulang ikan belida (Chitala sp.). Jurnal Ilmu Perikanan Tropis. 21(2): 32-40.

Koning AJ. 2002. Quantitative quality tests for fish meal. II. an investigation of the quality of south African fish meals and the validity of a number of chemical quality indices. International Journal of Food Properties. 5(3): 495-507.

Kusnandar F. 2011. Kimia Pangan: Komponen Makro. Jakarta (ID): Dian Rakyat.

Lakahena V, Didah NF, Rizal S, dan Peranginangin. 2014. Karakterisasi fisikokimia nanokalsium hasil ekstraksi tulang ikan nila menggunakan larutan basa dan asam. Jurnal Teknologi dan Industri Pangan. 25(1): 57-64.

Lasimpala R, Naiu AS, Mile L. 2014. Uji pembedaan ikan teri kering pada lama pengeringan berbeda dengan ikan teri komersial dari Desa Tolotio Kabupaten Bone Bolango Provinsi Gorontalo. Jurnal Ilmiah Perikanan Dan Kelautan. 2(2):8892.

Litaay C. 2012. Fortifikasi tepung ikan cakalang (Katsuwonus pelamis) terhadap karakteristik mie sagu. [Tesis]. Bogor (ID): Institut Pertanian Bogor.

Litaay C, Santoso J. 2013. Pengaruh perbedaan metode perendaman dan lama perendaman terhadap karakteristik fisiko-kimia tepung ikan cakalang (Katsuwonus pelamis). Jurnal Ilmu dan Teknologi Kelautan Tropis. 5(1): 85-92.

Machmud, MK, Dewi SS, Rossi RA.1990. Komposisi Zat Gizi Pangan Indonesia. Bogor (ID): Puslitbang Gizi.

Mikhail WZA, Sabhy HM, El-sayed HH, Khairy SA, Salem HYHA, Samy MA. 2013. Effect of nutritional status on growth pattern of stunted preschool children in Egypt. Journal of the Academy of Nutrition and Dietetics. 2(1): 1-9.

Murdiati, Agnes, Amaliah. 2013. Panduan Penyiapan Pangan Sehat Untuk Semua. Edisi 2, cetakan ke-1. Jakarta (ID): Kencana Prenadamedia Group.

Nandhani SD, Yunianta. 2015. Pengaruh 
tepung labu kuning, tepung lele dumbo, natrium bikarbonat terhadap sifat fisiko, kimia, organoleptik cookies. Jurnal Pangan dan Agroindustri. 3(3): 918-927

Nastiti AN, Christyaningsih J. 2019. Pengaruh substitusi tepung ikan lele terhadap pembuatan cookies bebas gluten dan kasein sebagai alternative jajanan anak autism spectrum disorder. Media Gizi Indonesia. 14(1): 35-43.

Nasution YS, Hendrik, Warningsih T. 2018. Analisis bioekonomi ikan teri nasi (Stolephorus commersonii) di Perairan Kabupaten Labuhanbatu Provinsi Sumatera Utara. Jurnal Perikanan dan Kelautan. 23(2): 38-46.

Nieves JW. 2005. Osteoporosis: the role of micronutrient. The American Journal of Clinical Nutrition. 81:1232-1239.

Nolsoe H, Inggrid U. 2009. The acid and alkaline solubilization process for the isolation of muscle proteins: state of the art. Food and Bioprocess Technology. 2(1): 1-27.

Nurani FP, Jariyah, Rosida, Susanti RA. 2018. Addition of anchovy flour and sodium bicarbonate to characteristics of high calcium. Proceedings International Conference on Science and Technology. 21-24.

Orlan, Asminaya NS, Nasiu F. 2019. Karakteristik fisiko kimia tepung ikan yang diberi pengawet bawang putih (Allium sativum) pada masa penyimpanan yang berbeda. Jurnal Agripet. 19(1): 6876.

Perana A. 2003. Penambahan ikan teri (Stolephorus sp) sebagai sumber protein dalam pembuatan tortilla chips. [skripsi]. Bogor (ID): Institut Pertanian Bogor.

Pomanto RM, Dali FA, Mile L. 2016. Pengaruh larutan asam alami terhadap mutu kimiawi tepung ikan manggapai. Jurnal Ilmiah Perikanan dan Kelautan. 4(3): 7580.

Pudyani SP. 2005. Reversibilitas klasifikasi tulang akibat kekurangan protein pre dan post natal. Dental Journal. 38(3): 115-119.

Purnasari G, Briawan D, Dwiriani CM. 2016. Asupan kalsium dan tingkat kecukupan kalsium pada ibu hamil di Kabupaten
Jember. Jurnal Media Kesehatan Masyarakat Indonesia. 2(4):265.

Putra TAW. 2013. Perbedaan kandungan kalsium (Ca) pada ikan teri nasi (Stolephorus spp.) lokal dan susu sapi lokal di Kabupaten Jember. [skripsi] Universitas Jember.

Rahmi Y, Widya NR, Anugerah PN, Tanuwijaya LK. 2018. Tepung ikan teri nasi (Stolephorus commersini Lac.) sebagai sumber kalsium dan protein pada corn flakes alternatif sarapan anak usia sekolah. Jurnal Nutrire Diaita. 10(1): 3444.

Rasyid HA. 2010. Pemanfaatan asap cair tempurung kelapa sebagai bahan pengawet ikan teri nasi (Stolephorus commersonii, Lac.) segar untuk tujuan transportasi [Skripsi]. Bogor (ID): Institut Pertanian Bogor.

Ritonga PS, Sukindro. 2012. Analisis kandungan fosfor menggunakan spectrophotometer UVVIS pada kacang hijau yang diambil dari pasar Kota Pekanbaru. Jurnal Photom. 2(2): 45-51.

Santoso J, Ling F, Handayani R. 2011. Pengaruh pengkomposisian dan penyimpanan dingin terhadap perubahan karakteristik surimi ikan pari (Trygon sp.) dan ikan kembung (Rastrelliger sp.). Jurnal Akuatika. 11(2): 145-159.

[SIG]. Saraswanti Indo Genetech. 2019. Instruksi Kerja (Dokumen Eksternal): Metode Uji Logam dan Mineral dalam Makanan, Pakan Ternal, Obat Herbal, dan Bahan Baku Secara ICP-OES No. 18-13-1/MU/SMM-SIG. Bogor (ID): SIG Laboratory.

Sediaoetama AD. 2006. Ilmu Gizi Untuk Mahasiswa dan Profesi. Jilid I. Jakarta (ID): Dian Rakyat.

Singh M. Role of micronutrients for physical growth and mental development. 2004. Indian Journal Pediatric. 71:59-62.

Solangi AA, Memon A, Qureshi TA, Leghari HH, Baloch GM, Wagan MP. 2002. Replacement of fish meal by soybeen meal in broiler ration. Journal of Animal and Veterinary Advances. 1: 28-30.

Stuijvenberg ME, Nel J, Schoeman SE, Lombard CJ, du Plessis LM, Dhansay 
MA. 2015. Low intake of calcium and vitamin $\mathrm{D}$, but not zinc, iron or vitamin $A$, is associated with stunting in 2-5 years old children. Nutrition. 31:841-846.

Subatin E. 2004. Pengaruh tingkat penambahan udang dan $\mathrm{NaHCO}_{3}$ (Natrium Bikarbonat) terhadap kadar protein, kadar air, daya kembang dan organoleptik kerupuk susu [skripsi]. Malang (ID): Universitas Muhammadiyah.

Sudarmadji S, Haryono B, Suhardi. 1997. Prosedur Analisa Untuk Bahan Makanan dan Pertanian. Yogyakarta (ID): Liberty.

Turan H, Kaya Y, Erkoyuncu I. 2007. Protein and lipid content and fatty acid composition of anchovy meal produced in Turkey. Turkish Journal of Veterinary and Animal Sciences. 31(2): 113-117.

Trilaksani W, Salamah E, and Nabil M. 2006. Pemanfaatan limbah tulang ikan tuna (Thunnus sp.) sebagai sumber kalsium dengan metode hidrolisis protein. Buletin Teknologi Hasil Perikanan. 9(2): 34-45.

Orlan, Asminaya NS, Nasiu F. 2019. Karakteristik fisiko kimia tepung ikan yang diberi pengawet bawang putih (Allium sativum) pada masa penyimpanan yang berbeda. Jurnal Agripet. 19(1):68-76. Winarno FG. 2004. Kimia Pangan dan Gizi. Jakarta (ID): Gramedia Pustaka Utama.

Wood BJB. 1989. Microbiology of Fermented Food. London (UK): Elsevier Applied Science Publishers. 